\title{
Pengaruh Pembelajaran Daring Dengan Perpaduan Asinkronous Dan Sinkronous Terhadap Minat Dan Prestasi Belajar Ekonomi
}

\author{
Anak Agung Ketut Agung Widiantari ${ }^{*}$, I Gede Astra Wesnawaํㅗ I Wayan Mudana1 \\ 1 Universitas Pendidikan Ganesha, Indonesia \\ *e-mail: agungwidiantari2122@gmail.com
}

Article history: Received 08 July 2021; Accepted 05 August 2021; Available online 31 August2021

\begin{abstract}
Abstrak
Penelitian ini bertujuan untuk mengetahui pengaruh pembelajaran daring dengan perpaduan asinkronous dan sinkronous terhadap minat dan prestasi belajar siswa IPS (Ekonomi) di masa pendemi Covid 19. Penelitian ini adalah penelitian eksperimen semu dengan rancangan posttest only control group design. Populasi dalam penelitian ini berjumlah 72, sedangkan sampel berjumlah 48 orang siswa yang dipilih dengan teknik simple random sampling. Variabel bebas dalam penelitian ini adalah pembelajaran daring dengan Perpaduan Asinkronous dan Sinkronous, sedangkan variabel terikat dalam penelitian ini adalah minat belajar dan prestasi belajar siswa. Data minat belajar siswa dikumpulkan dengan metode kuesioner, sedangkan data prestasi belajar siswa dikumpulkan dengan metode tes. Analisis data yang digunakan pada penelitian ini adalah Manova. Berdasarkan penelitian yang telah dilakukan disimpulkan bahwa: terdapat pengaruh yang signifikan pembelajaran daring dengan perpaduan Asinkronus dan Sinkronus terhadap minat dan prestasi belajar siswa kelas X IPS baik secara terpisah maupun bersama-sama.
\end{abstract}

\begin{abstract}
This study aims to determine the effect of online learning with a combination of asynchronous and synchronous on the interest and learning achievement of social studies (Economics) students during the Covid 19 pandemic. This study is a quasi-experimental study with a posttest only control group design. The population in this study amounted to 72 , while the sample amounted to 48 students who were selected by simple random sampling technique. The independent variable in this study is online learning with a combination of asynchronous and synchronous, while the dependent variable in this study is interest in learning and student achievement. Data on student interest in learning was collected using the questionnaire method, while data on student achievement was collected using the test method. Analysis of the data used in this study is Manova. Based on the research that has been done, it can be concluded that: there is a significant effect of online learning with a combination of Asynchronous and Synchronous on the interest and learning achievement of students of class X Social Sciences, either separately or together.
\end{abstract}

Kata Kunci:

Daring; Asinkronous, Sinkronous; Minat Belajar; Prestasi Belajar

\section{Keywords:}

Online; Asynchronous, Synchronous; Interest in Learning; Learning Achievement

\section{Pendahuluan}

Menteri Pendidikan dan Kebudayaan RI, Nadiem Anwar Makarim telah mengeluarkan beberapa kebijakan untuk mengatur kegiatan pembelajaran selama masa pandemi ini. Hal tersebut dikeluarkan melalui Surat edaran Nomor 4 Tahun 2020, yaitu tentang Pelaksanaan 
Kebijakan Pendidikan dalam Masa Darurat Penyebaran Coronavirus Disease (Covid-19), tertanggal 24 Maret 2020. Tepatnya ada 6 (enam) kebijakan yang dipaparkan dengan jelas.

Namun, yang paling mendasar adalah merubah cara belajar mengajar siswa dan guru adalah kebijakan belajar dari rumah. Kebijakan belajar dari rumah ini sangat merubah kebiasaan, ataupun prilaku guru dan siswa selama ini. Bagaimana tidak, selama ini guru mengajar di kelas dalam artian mengajar di sebuah bangunan sekolah yang memiliki fungsi belajar mengajar, dengan didukung oleh sarana penunjang proses belajar mengajar tersebut. Dengan kebijakan baru ini guru dibuat kelimpungan karena masih mencari pola yang tepat bagaimana pembelajaran dari rumah itu bisa dilakukan. Jalan terbaik yaitu melakukan atau mengupayakan pembelajaran berbasis dalam jaringan. Nama lainnya adalah pembelajaran daring (online learning).

Dalam lingkungan saat ini jenis pembelajaran yang terjadi umumnya dibagi ke dalam salah satu dari dua kategori: sinkronous dan asinkronous. Kedua strategi memiliki pro dan kontra dan teknik yang tepat untuk peserta didik sangat tergantung pada metode menyerap informasi yang disediakan. Sinkronous e-learning adalah percakapan online dan konferensi video. Alat pembelajaran digunakan secara real-time, seperti instant messaging yang memungkinkan siswa dan guru untuk bertanya dan menjawab pertanyaan dengan segera dan sinkron (dalam waktu yang bersamaan). Contohnya, teks chat dan video call Dibandingkan dengan belajar sendiri, peserta didik yang mengikuti program sinkronous learning dapat berinteraksi dengan peserta didik lain dan juga pengajar selama pelajaran berlangsung. Manfaat utama dari sinkronous learning adalah hal tersebut dapat memungkinkan siswa untuk menghindari perasaan terisolir dalam berkomunikasi dengan orang lain selama proses pembelajaran. Namun sinkronous learning tidak fleksibel dalam hal waktu, sebagai peserta didik dalam sinkronous learning harus menyisihkan waktu tertentu untuk menghadiri sesi pengajaran secara langsung (live) atau kursus online secara real-time. Sedangkan asinkronous learning disisi lain dapat dilakukan bahkan ketika peserta didik atau pengajar sedang offline. Contohnya seperti, e-mail, forum, dan lain-lainnya.

Idealnya, program e-learning efektif harus mencakup kegiatan belajar baik asinkronous dan sinkronous. Hal ini memungkinkan peserta didik dan pengajar untuk mendapatkan keuntungan dari format pengiriman yang berbeda terlepas dari jadwal mereka atau metode pembelajaran disukai. Pendekatan ini memberikan siswa dengan akses bantuan segera jika diperlukan, sementara masih memberi mereka kemampuan untuk belajar dengan kecepatan atau kemampuan mereka sendiri. Dimana sistem pembelajaran secara online ini dilaksanakan melalui perangkat personal computer (PC) atau laptop bahkan Handphone yang terhubung dengan koneksi jaringan internet. Guru dapat melakukan pembelajaran bersama diwaktu yang sama menggunakan grup di media sosial seperti WhatsApp (WA), telegram, aplikasi zoom atau google meet dan google classroom ataupun media lainnya sebagai media pembelajaran. Dengan demikian, guru dapat memastikan siswa mengikuti pembelajaran dalam waktu yang bersamaan, meskipun di tempat yang berbeda.

Pembelajaran ini sangat berbeda dengan pembelajaran konvensional yang terjadi di sekolah. Guru dan siswa tidak berhadapan langsung, melainkan terjadi secara jarak jauh yang memungkinkan guru dan siswa berada pada tempat yang berbeda. Secara positif pembelajaran ini sangat membantu keberlangsungan pembelajaran di masa pandemi ini. Guru dan siswa akan tetap aman berada pada tempat atau rumahnya masing-masing tanpa harus keluar rumah dan bertatap muka secara langsung. Namun, merubah pola atau kebiasaan sangatlah sulit, dan merupakan hal wajar ketika terjadi perubahan yang sangat cepat dan tidak terduga. Kebiasaan yang berubah secara signifikan ini misalnya, guru dan siswa sangat mengandalkan perangkat komputer dan jaringan internet, itu yang pertama. Kedua, Guru dan siswa harus mampu merubah gaya, strategi atau metode mengajar dan belajar. Ketiga, guru dan siswa harus mampu merubah gaya komunikasinya selama pembelajaran daring ini. Banyak guru yang tidak memperhatikan 
bagian yang ketiga ini, yaitu kurangnya pemahaman dan penerapan guru dalam berkomunikasi dengan siswanya. Guru biasanya berkomunikasi satu atau dua arah di sekolah, dengan bertatap muka secara langsung melakukan diskusi dan latihan secara bersama - sama.

Berdasarkan observasi yang dilakukan pada siswa kelas X IPS di SMA Jembatan Budaya, proses pembelajaran yang dilakukan oleh guru dan siswa adalah pembelajaran dalam jaringan (daring). Proses pembelajaran daring yang dilaukan oleh guru dan siswa cenderung hanya menggunakan media sosial WhatsApp (WA) saja. Hal ini menyebabkan proes pembelajaran menjadi monoton. Permasalahan yang terjadi pada pelaksanaan pembelajaran daring yang telah dilakukan adalah: Pertama, tidak mewakili emosi pemakainya dalam hal ini guru dan siswa. Sehingga guru sangat sulit dalam memberikan pemahaman kepada siswa, dan guru tidak mengetahui sejauh mana tingkat pemahaman siswanya. Kedua, terdapat informasi yang tidak penting, atau informasi yang didapat akan sangat banyak dan sulit untuk disaring dan dikontrol, sehingga penerima informasi akan menjadi bingung. Ketiga, sangat menyita konsentrasi karena tidak sesuai dengan tempat dan waktunya, sehingga time management harus dikedepankan.

Permasalahan ini membuat minat belajar siswa terutama dalam pembelajaran Ekonomi menjadi rendah. Hal ini tercermin dari keaktifan siswa dalam membalasan pesan guru di group WA yang telah dibuat, terkesan sekedarnya saja. Dan ada beberapa siswa juga sering terlambat dalam mengumpulkan tugas. Rendahnya minat belajar siswa dalam pembelajaran ekonomi ini berdampak negative terhadap prestasi belajar ekonomi siswa. Berdasarkan nilai tugas yang telah dinilai guru, didapatkan rata-rata nilai ekonomi siswa sebesar 65, sedangkan KKM yang ditetapkan sekolah yakni 70. Hasil ini menandakan adanya siswa yang belum tuntas dalam mengikuti proses pembelajaran ekonomi yang diberikan oleh guru.

Untuk mengatasi permasalahan di atas, dicarilah sebuah aplikasi yang bisa mewadahi dan melengkapi kendala di atas. Yaitu menggunakan aplikasi Google Meet (Daring Sinkronus) dan Google Classroom (Daring Asinkronus). Kedua aplikasi daring tersebut yang saat ini para guru gunakan sebagai media pembelajaran jarak jauh, SMA Jembatan Budaya merupakan salah satu Sekolah Menengah Atas Swasta yang berada di Kabupaten Badung Provinsi Bali, Indonesia. Sama dengan SMA pada umumnya di Indonesia masa pendidikan sekolah di SMA Jembatan Budaya ditempuh dalam waktu tiga tahun pelajaran, mulai dari Kelas X sampai Kelas XII. SMA Jembatan Budaya beralamat di Jalan. Raya Kuta No.1.. Berbagai fasilitas dimiliki untuk menunjang kegiatan belajar mengajar.

Fasilitas tersebut antara lain yaitu Ruang Kelas, Ruang UNBK, Perpustakaan, Laboratorium, Ruang Multimedia, Ruang Audiovisual, Ruang UKS, Ruang Kegiatan Ekstrakurikuler, Lapangan Olahraga, Kantin, dan Taman. SMA Jembatan Budaya mempunyai dua program jurusan yaitu IPA, dan IPS. Dan menggunakan Kurikulum 2013 dimulai dari tahun ajaran 2018/2019. Berdasarkan uraian latar belakang di atas, yang mana peneliti mempunyai keinginan untuk mengetahui bagaimana tingkat pemahaman siswa saat menggunakan media pembelajaran online. Maka peneliti tertarik untuk mengadakan penelitian yang berjudul Pengaruh Pembelajaran Daring dengan Perpaduan Asinkronus dan Sinkronus Terhadap Minat dan Prestasi Belajar Siswa IPS (Ekonomi) di Masa Pendemi Covid 19".

Tujuan dari diadakannya penelitian ini adalah untuk mengetahui perbedaan minat belajar siswa kelas X IPS antara siswa yang mengikuti pembelajaran daring dengan perpaduan Asinkronus dan Sinkronus dan siswa yang mengikuti pembelajaran konvensional. Untuk mengetahui perbedaan prestasi belajar siswa kelas X IPS antara siswa yang mengikuti pembelajaran daring dengan perpaduan Asinkronus dan Sinkronus dan siswa yang mengikuti pembelajaran konvensional. Untuk mengetahui perbedaan secara bersama-sama, minat dan 
prestasi belajar siswa kelas X IPS antara siswa yang mengikuti pembelajaran daring dengan perpaduan Asinkronus dan Sinkronus dan siswa yang mengikuti pembelajaran konvensional.

\section{Metode}

Penelitian ini dilaksanakan pada Kelas X IPS semester II tahun pelajaran 2020/2021. Penelitian ini adalah penelitian eksperimen. Dikarenakan pada penelitian ini tidak mungkin mengubah kelas/sampel yang sudah dibentuk, maka penelitian ini tergolong penelitian Quasi Eksperimental Design. Quasi eksperimental design mempunyai kelompok kontrol, tetapi tidak dapat berfungsi sepenuhnya untuk mengontrol variabel-variabel luar yang mempengaruhi pelaksanaan eksperimen (Sugiyono, 2010). Rancangan penelitian ini menggunakan posttest only control group design.

Populasi dalam penelitian ini adalah seluruh siswa kelas X IPS di SMA Jembatan Budaya. Sebaran jumlah siswa dalam populasi penelitian ini dapat dilihat pada Tabel 1.

Tabel 1. Populasi Penelitian

\begin{tabular}{lll}
\hline No & Kelas & Jumlah Siswa \\
\hline 1 & X IPS 1 & 24 \\
\hline 2 & X IPS 2 & 24 \\
\hline 3 & X IPS 3 & 24 \\
\hline Jumlah & & 72 \\
\hline
\end{tabular}

Dalam penentuan sampel pada penelitian ini menggunakan teknik random sampling. Namun, sebelum melakukan teknik random sampling, terlebih dahulu sampel diuji kesetaraannya menggunakan analisis uji t. Nilai yang digunakan dalam uji t adalah nilai UTS siswa di semester II. Adapun hasil uji kesetaraannya seperti terlihat pada Tabel 2.

Tabel 2. Hasil Uji Kesetaraan

\begin{tabular}{llll}
\hline No & Pasangan Kelas & Signifikansi & Keternagan \\
\hline 1 & X IPS 1 - X IPS 2 & 0,976 & Setara \\
\hline 2 & X IPS 1 - X IPS 3 & 0,532 & Setara \\
\hline 3 & X IPS 2 - X IPS 3 & 0,442 & Setara \\
\hline
\end{tabular}

Setelah diketahui seluruh populasi dalam penelitian ini memiliki kemampuan yang setara, maka selanjutnya dilakukan teknik random sampling dengan cara undian untuk memilih kelas eksperimn dan kelas kontrol. Berdasarkan undian yang telah dilakukan didapatkan hasil seperti terlihat pada Tabel 3.

Tabel 3. Sampel Penelitian

\begin{tabular}{lll}
\hline No & Kelas & Keterangan \\
\hline 1 & X IPS 3 & Eksperimen \\
\hline 2 & X IPS 2 & Kontrol \\
\hline
\end{tabular}

Variabel dalam penelitian ini dapat dikelompokkan menjadi variabel bebas (X) dan variabel terikat (Y). Variabel bebas pada penelitian ini adalah Pembelajaran Daring dengan Perpaduan Asinkronous dan Sinkronous. Sedangkan variabel terikatnya adalah minat dan prestasi belajar siswa. 
Materi yang diberikan pada penelitian ini adalah: (1) mendeskripsikan Lembaga Jasa Keuangan dalam Perekonomian, (2) mendeskripsikan Bank Sentral, Sistem Pembayaran, dan Alat Pembayaran dalam Perekonomian Indonesia, (3) mendeskripsikan konsep Badan Usaha dalam Perekonomian Indonesia, (4) mendeskripsikan Perkoperasian dalam Perekonomian Indonesia, dan (5) mendeskripsikan konsep Manajemen.

Data yang dikaji pada penelitian ini adalah tentang minat dan prestasi belajar siswa. Data minat belajar diperoleh melalui pemberian metode angket/kuesioner dan data prestasi belajar diperoleh melalui tes objektif tipe pilihan ganda yang disusun dengan bimbingan dan persetujuan dari beberapa ahli (judges).

Data yang sudah dikumpulkan ditabulasi rerata dan simpangan baku menyangkut data minat dan prestasi belajar. Analisis statistik yang digunakan untuk menguji hipotesis adalah dengan menggunakan MANOVA, diakrenakan pada penelitian ini menyelidiki pengaruh satu variabel bebas terhadap dua variabel terikat.

Hipotesis yang diajukan pada penelitian ini adalah sebagai berikut.

1) Terdapat perbedaan yang signifikan minat belajar siswa kelas X IPS antara siswa yang mengikuti pembelajaran daring dengan perpaduan Asinkronus dan Sinkronus dan siswa yang mengikuti pembelajaran konvensional.

2) Terdapat perbedaan yang signifikan prestasi belajar siswa kelas X IPS antara siswa yang mengikuti pembelajaran daring dengan perpaduan Asinkronus dan Sinkronus dan siswa yang mengikuti pembelajaran konvensional.

3) Secara bersama-sama, terdapat perbedaan yang signifikan minat dan prestasi belajar siswa kelas X IPS antara siswa yang mengikuti pembelajaran daring dengan perpaduan Asinkronus dan Sinkronus dan siswa yang mengikuti pembelajaran konvensional.

\section{Hasil dan Pembahasan}

Pada Penelitian ini menggunakan media pembelajaran secara daring dimana perpaduan antara media Asinkronous dan Sinkronous. Media daring secara Asinkronous saya gunakan (Line Group dan Google Classroom) ketika untuk berkomunikasi dan menyampaikan informasi kepada para siswa terkait penyampaian informasi pembelajaran, presensi, dan informasi tugas-tugas setiap materi yang sudah dibahas serta share link penilaian evaluasi yang akan dilakukan kepada siswa. Sedangkan Media daring secara Sinkronous (Google Zoom dan Google Meet) digunakan saat diadakannya tatap muka secara virtual (online) kepada peserta didik saat akan melakukan pembelajaran. Dimana kegiatan tatap muka ini biasanya guru dan siswa bisa saling berkomunikasi secara online membahas materi yang sudah dipresentasikan dan didiskusikan.

Partisipasi peserta didik saat melakukan pembelajaran dengan perpaduan daring Asinkronous dan Sinkronous ini sangat tinggi dan antusias. Dikarenakan hanya media ini yang mampu memberikan solusi disaat kondisi pandemi sekarang ini. Dan juga dengan media semacam ini tujuan pembelajaran dapat tersampaikan kepada peserta didik yang rata-rata peserta didik dijenjang SMA sudah semua memiliki kemampuan IT jadi sangat memudahkan mengoperasikan aplikasi yang digunakan. Selain itu peserta didik juga merasa lebih nyaman dengan perpaduan media daring ini karena bukan sekedar dishare materi dan tugas saja tetapi saat tatap muka online peserta didk dapat mengkomunikasikan kendala/hambatan terkait materi pembelajaran langsung jadi tidak ada lagi rasa kurang diperdulikan atau guru tidak mau mengetahui keluh kesah para siswa saat pembelajaran online ini berlangsung. Jadi media daring ini sangat membantu dalam system pembelajaran online tersebut.

Setiap media/system yang digunakan pasti ada kendala/hambatan yang terjadi dilapangan. Dalam Penelitian ini yang sering terjadi kendalanya yaitu koneksi/sinyal yang kurang bersahabat 
disaat tertentu baik dari guru maupun siswanya. Selain koneksi terkadang masih ada siswa yang kurang persiapan saat pembelajaran akan berlangsung seperti lupa mengisi link presensi, hadir saat tatap muka online terlambat dan lupa kirimkan tugas yang sudah diinformasikan. Solusi yang sudah diterapkan saat menggunakan media ini yaitu dengan tetap berkomunikasi kepada siswanya, contohnya jika terjadi kendala sinyal/koneksi guru akan chat di group siswa yang belum join kelas dan sebaliknya jika hambatan koneksi salah satu aplikasi bermasalah alternatifnya dengan pindah menggunakan aplikasi yang lain seperti G.Zoom/G.Meet. Jika terlambat masuk kelas guru mapel tetap berkomunikasi di group chat dengan mengetag nama siswa yang tanpa konfirmasi sebelumnya dan kendala Ketika siswa lupa atau belum mengirimkan tugasnya,tetap guru akan menginfokan digroup siswa yang belum mengumpukan tugas sesuai deadline yang sudah ditentukan.Setiap media yang digunak dalam penelitian ini ada kelebihan dan kekurangannya. Dimana media Asinkronous yang digunakan disini kelebihannya untuk berkomunikasi lebih cepat dan dalam penyampaian informasi juga jelas diuraikan, fitur-fitur yang tersedia juga banyak dapat digunakan serta dalam penilaian/evaluasi lebih efektif karena nilai siswa bisa langsung terlihat dan siswa juga dapat melihat hasilnya lebih cepat. Sedangkan kelemahannya yang sering terjadi yaitu koneksi saat kondisi tertentu yang tiba-tiba hilang dan harus direview kembali. Sedangkan dari media Sinkronous kelebihannya lebih mudah untuk berkomunikasi langsung tatap muka walaupun secara online bisa membuat suasana kelas lebih hidup dengan adanya komunikasi 2 arah dan dapat mengetahui kendala yang dihadapi siswa saat pembelajaran, lebih mudah mempresentasikan materi dilayar monitor dan siswa juga dapat lebih jelas melihatnya. Kelemahannya selainnya sinyal, aplikasi ini belum banyak yang gratis dan ada yang menyesuaikan waktu dan peserta yang masuk join dalam virtual ini menyesuaikan dengan kapasitasnya.

Berdasarkan penelitian yang telah dilakukan dengan menerapkan pembelajaran daring dengan perpaduan asinkronous dan sinkronous didapatkan hasil sebagai berikut. Penelitian ini mengumpulkan data tentang minat belajar dan prestasi belajar IPS dari kelompok siswa yang mengikuti pembelajaran daring dengan perpaduan asinkronous dan sinkronous dan kelompok yang mengikuti pembelajaran konvensional. Deskripsi data hasil penelitian secara umum seperti terlihat pada Tabel 4.

Tabel 4. Deskripsi Data Hasil Penelitian

\begin{tabular}{|c|c|c|c|c|}
\hline Statistik & A1Y1 & $\mathrm{A} 2 \mathrm{Y} 1$ & A1Y2 & $\mathrm{A} 2 \mathrm{Y} 2$ \\
\hline Mean & 85,13 & 28,46 & 75,29 & 23,54 \\
\hline Median & 85 & 28 & 75 & 24 \\
\hline Modus & 86 & 25 & 74 & 24 \\
\hline Standar Deviasi & 3,57 & 2,87 & 4,06 & 2,52 \\
\hline Varians & 12,72 & 8,26 & 16,48 & 6,35 \\
\hline Range & 16 & 9 & 16 & 10 \\
\hline Skor Minimum & 78 & 25 & 67 & 18 \\
\hline Skor Maksimum & 94 & 34 & 83 & 28 \\
\hline Jumlah & 2043 & 683 & 1807 & 565 \\
\hline
\end{tabular}

Keterangan

A1Y1 : Deskripsi data minat belajar siswa yang mengikuti pembelajaran daring dengan perpaduan asinkronous dan sinkronous

A2Y1 : Deskripsi data minat belajar siswa yang mengikuti pembelajaran konvensional

A1Y2 : Deskripsi data prestasi belajar IPS siswa yang mengikuti pembelajaran daring dengan perpaduan asinkronous dan sinkronous

A2Y2 : Deskripsi data prestasi belajar IPS siswa yang mengikuti pembelajaran konvensional 
Berdasarkan tabel 4 di atas, data tentang minat belajar yang mengikuti pembelajaran daring dengan perpaduan asinkronous dan sinkronous mendapatkan rentangan $=16, \mathrm{n}=24$, skor minimum $=78$, skor maksimum $=94$, rata-rata $=85,13$, median $=85$, modus $=86$, standar deviasi $=3,57$, dan varians $=12,72$. Jika dilihat dari rata-rata $($ mean $)=85,13$ dan dikonversikan ke dalam tabel di atas, dapat diketahui bahwa kencederungan data minat belajar siswa yang mengikuti pembelajaran daring dengan perpaduan asinkronous dan sinkronous masuk dalam kategori sangat tinggi.

Data tentang minat belajar siswa yang mengikuti pembelajaran konvensional mempunyai rentangan $=16, \mathrm{n}=24$, skor minimum $=67$, skor maksimum $=83$, rata-rata $=75,29$, median $=75$, modus $=74$, standar deviasi $=4,06$, dan varians $=16,48$. Jika dilihat dari rata-rata $($ mean $)=75,29$ dan dikonversikan ke dalam tabel di atas, dapat diketahui bahwa kencederungan data minat belajar siswa yang mengikuti pembelajaran konvensional masuk dalam kategori tinggi.

Data tentang prestasi belajar IPS yang mengikuti pembelajaran daring dengan perpaduan asinkronous dan sinkronous mempunyai rentangan $=9, \mathrm{n}=24$, skor minimum $=25$, skor maksimum $=34$, rata-rata $=28,46$, median $=28$, modus $=25$, standar deviasi $=2,87$, dan varians $=8,26$. Jika dilihat dari rata-rata (mean) $=28,46$ dan dikonversikan ke dalam tabel di atas, dapat diketahui bahwa kencederungan data data prestasi belajar IPS siswa yang mengikuti pembelajaran daring dengan perpaduan asinkronous dan sinkronous masuk dalam kategori sangat tinggi.

Data tentang prestasi belajar IPS yang mengikuti pembelajaran konvensional mempunyai rentangan $=10, \mathrm{n}=24$, skor minimum $=18$, skor maksimum $=28$, rata-rata $=23,54$, median $=24$, modus $=24$, standar deviasi $=2,52$, dan varians $=6,35$. Jika dilihat dari rata-rata (mean) $=23,54$ dan dikonversikan ke dalam tabel di atas, dapat diketahui bahwa kencederungan data prestasi belajar IPS siswa yang mengikuti pembelajaran konvensional masuk dalam kategori tinggi.

Berdasarkan pengujian hipotesis yang telah dilakukan, didapatkan hasil sebagai berikut.

1) Pengaruh Pembelajaran Daring dengan Perpaduan Asinkronus dan Sinkronus terhadap Minat Belajar Siswa Kelas X IPS

Berdasarkan pengujian hipotesis pertama didapatkan hasil bahwa: terdapat pengaruh yang signifikan pembelajaran daring dengan perpaduan Asinkronus dan Sinkronus terhadap minat belajar siswa kelas X IPS dengan $F_{\text {hitung }}$ sebesar 79,477 dan signifikansi 0,00.

Berdasarkan analisis deskriptif yang telah dilakukan, didapatkan rata-rata minat belajar siswa yang mengikuti pembelajaran daring dengan perpaduan Asinkronus dan Sinkronus sebesar 85,13 . Sedangkan rata-rata minat belajar siswa yang mengikuti pembelajaran konvensional sebesar 75,29. Hasil ini menandakan minat belajar siswa yang mengikuti pembelajaran daring dengan perpaduan Asinkronus dan Sinkronus lebih baik daripada minat belajar siswa yang mengikuti pembelajaran konvensional.

Hasil penelitian ini sejalan dengan hasil penelitian yang dilakukan oleh Jusmawati (2020) dengan judul Pengaruh Pembelajaran Berbasis Daring Terhadap Minat Belajar Mahasiswa PGSD Unimerz Pada Mata Kuliah Pendidikan Matematika. Dalam penelitiannya dinyatakan bahwa: terdapat pengaruh pembelajaran berbasis daring terhadap minat belajar matematika mahasiswa Prodi PGSD Universitas Megarezky.

Penelitian yang dilakukan oleh Nurfani (2020) dengan judul Pengaruh Kuliah Online Terhadap Minat Belajar Mahasiswa Pendidikan Agama Islam (PAI) di IAIN Samarinda. Dalam penelitiannya disimpulkan bahwa ada pengaruh yang signifikan antara kuliah online dengan minat belajar mahasiswa PAI di IAIN Samarinda dengan nilai koefisien korelasi (r) $=0.975$ dapat dimaknai bahwa besarnya sumbangan variabel kuliah online terhadap minat belajar mahasiswa PAI di IAIN Samarinda sebesar 95.06\%. 
Selanjutnya penelitian yang dilakukan oleh Jamil (2020) dengan judul Pengaruh Pembelajaran Daring Terhadap Minat Belajar Mahasiswa Pada Masa Pandemik Covid-19. Hasil penelitian menunjukkan bahwa sikap penggunaan internet, persepsi, pengalaman, kondisi finansial berpengaruh signifikan terhadap minat belajar mahasiswa. Sedangkan kemampuan belajar mandiri tidak memberikan pengaruh yang signifikan terhadap minat belajar mahasiswa selama perkuliahan daring.

Minat belajar adalah kecenderungan hati yang tinggi untuk belajar, mendapatkan informasi, pengetahuan, kecakapan, melalui usaha, pengajaran atau pengalaman. Belajar dengan minat akan mendorong peserta didik untuk belajar lebih baik daripada belajar tanpa minat, minat akan timbul apabila peserta didik tertarik akan sesuatu karena sesuai dengan kebutuhannya atau merasakan bahwa sesuatu yang akan dipelajarinya bermakna bagi dirinya (Setiabudi, 2008).

Kegiatan pembelajaran daring Asinkronus dalam penelitian ini menggunakan media aplikasi WhatsApp, Line, dan Email. Sedangkan pembelajaran daring Sinkronus dalam penelitian ini menggunakan media aplikasi Google Meet. Penerapan pembelajaran daring dengan perpaduan Asinkronus dan Sinkronus membuat siswa lebih bersemangat belajar daring. Hal ini dikarenakan proses pembelajaran lebih bervariasi, dan pada beberapa materi siswa dapat langsung mendengarkan penjelasan dari guru, sehingga meminimalkan miskonsepsi dalam kegiatan pembelajaran. Berdasarkan pemaparan di atas, dapat disimpulkan bahwa minat belajar siswa yang mengikuti pembelajaran daring dengan perpaduan Asinkronus dan Sinkronus lebih baik daripada minat belajar siswa yang mengikuti pembelajaran konvensional.

2) Pengaruh Pembelajaran Daring dengan Perpaduan Asinkronus dan Sinkronus terhadap Prestasi Belajar Siswa Kelas X IPS

Berdasarkan pengujian hipotesis kedua didapatkan hasil bahwa: terdapat pengaruh yang signifikan pembelajaran daring dengan perpaduan Asinkronus dan Sinkronus terhadap prestasi belajar siswa kelas X IPS dengan Fhitung sebesar 39,724 dan signifikansi 0,00.

Berdasarkan analisis deskriptif yang telah dilakukan, didapatkan rata-rata prestasi belajar IPS siswa yang mengikuti pembelajaran daring dengan perpaduan Asinkronus dan Sinkronus sebesar 28,46 . Sedangkan rata-rata prestasi belajar IPS siswa yang mengikuti pembelajaran konvensional sebesar 23,54. Hasil ini menandakan prestasi belajar IPS siswa yang mengikuti pembelajaran daring dengan perpaduan Asinkronus dan Sinkronus lebih baik daripada prestasi belajar IPS siswa yang mengikuti pembelajaran konvensional.

Hasil penelitian ini sejalan dengan hasil penelitian yang dilakukan oleh Ferazona (2020) dengan judul Pengaruh Pembelajaran Daring Terhadap Hasil Belajar Kognitif Mahasiswa Pada Mata Kuliah Limnologi. Dalam penelitiannya dinyatakan bahwa hasil belajar kognitif mahasiswa diperoleh pada kategori sangat baik dengan persentasi 53,33\% dan baik dengan persentase 46,66\%. Hal ini membuktikan bahawa hasil belajar kognitif mahasiswa pada mata kuliah limnologi Selama Pandemik Covid-19 memperoleh hasil yang sangat baik dan baik.

Selanjutnya hasil penelitian yang dilakukan oleh Nugraha, Sobron Adi, (2020) dengan judul Studi Pengaruh Daring Learning Terhadap Hasil Belajar Matematika Kelas IV. Hasil penelitian ini dapat disimpulkan bahwa terdapat pengaruh penggunaan media Daring Learning terhadap hasil belajar matematika siswa kelas IV. Nilai rata-rata post test menunjukkan bahwa kelas eksperimen lebih tinggi dibandingkan kelas control yaitu sebesar 80,83 kelas eksperimen dan 64,14 untuk kelas kontrol.

Pembelajaran adalah proses interaksi peserta didik dengan pendidik dan sumber belajar pada suatu lingkungan belajar. Pembelajaran merupakan bantuan yang diberikan pendidik agar dapat terjadi proses pemerolehan ilmu dan pengetahuan, penguasaan kemahiran dan tabiat, serta pembentukan sikap dan kepercayaan pada peserta didik. Proses pembelajaran daring dengan 
perpaduan Asinkronus dan Sinkronus pada masa pandemi covid 19 ini memungkinkan siswa untuk dapat berinteraksi lebih intens baik dengan guru maupun teman-temannya.

Pada pembelajaran daring dengan perpaduan Asinkronus dan Sinkronus siswa akan lebih merasa diperhatikan dalam belajar karena guru dan siswa dapat berinteraksi secara virtual. Proses pembelajaran seperti ini juga memudahkan guru dalam menilai sikap dan kemampun siswa. Hal ini dikarenakan guru dapat berdiskusi langsung dengan siswa dalam proses pembelajaran, sehingga guru akan mampu menilai secara objektif dalam proses pembelajaran. Hal ini pun juga dapat memacu semangat siswa dalam belajar, sehingga prestasi belajar IPS siswa dapat ditingkatkan secara optimal.

Berdasarkan pemaparan di atas, dapat disimpulkan bahwa prestasi belajar IPS siswa yang mengikuti pembelajaran daring dengan perpaduan Asinkronus dan Sinkronus lebih baik daripada prestasi belajar IPS siswa yang mengikuti pembelajaran konvensional.

3) Secara bersama-sama, Pengaruh Pembelajaran Daring dengan Perpaduan Asinkronus dan Sinkronus terhadap Minat dan Prestasi Belajar Siswa Kelas X IPS

Pembelajaran Daring dengan Perpaduan Asinkronus dan Sinkronus pada masa pandemi covid 19 memberikan dampak yang positif terhadap minat dan prestasi belajar siswa. Hal ini dibuktikan dari pengujian hipotesis ketiga pada penelitian ini didapatkan hasil bahwa: secara bersama-sama, terdapat pengaruh yang signifikan pembelajaran daring dengan perpaduan Asinkronus dan Sinkronus terhadap minat dan prestasi belajar siswa kelas X IPS dengan $\mathrm{F}_{\text {hitung }}$ sebesar 50,575 dan signifikansi 0,00.

Hasil penelitian ini diperkuat dengan hasil penelitian yang dilakukan oleh Sutriyani (2020) dengan judul Studi Pengaruh Daring Learning Terhadap Minat dan Hasil Belajar Matematika Mahasiswa PGSD Era Pandemi Covid-19. Dalam penelitiannya disimpulkan bahwa penggunaan daring learning pada mata kuliah pembelajaran matematika SD berpengaruh positif pada hasil belajar mahasiswa PGSD FTIK Unisnu Jepara.

Penelitian yang dilakukan oleh Sijabat, Apriani (2020) dengan judul Pengaruh Pembelajaran Daring Terhadap Minat Belajar Mahasiswa Pendidikan Fisika Uhkbpnp Pada Matakuliah Fisika Umum. Hasil penelitian ini menunjukkan bahwa terdapat pengaruh pembelajaran berbasis daring terhadap minat belajar fisika umum mahasiswa Prodi Pendidikan Fisika Universitas HKBP Nommensen Pematangsiantar.

Melalui pembelajaran daring dengan perpaduan Asinkronus dan Sinkronus membuat guru dan siswa lebih bersemangat dalam melaksanakan proses pembelajaran. Perpaduan metode pembelajaran Asinkronus dan Sinkronus membuat siswa lebih bisa mengungkapkan apa yang dipahami siswa dalam proses pembelajaran. Rasa jenuh siswa dalam belajar di rumah pun dapat berkurang. Selain itu, proses perpaduan metode pembelajaran ini dapat meringankan kerinduan siswa, baik dengan guru maupun teman-temannya.

Berdasarkan pemaparan di atas, dapat disimpulkan bahwa minat dan prestasi belajar siswa siswa yang mengikuti pembelajaran daring dengan perpaduan Asinkronus dan Sinkronus lebih baik daripada minat dan prestasi belajar siswa yang mengikuti pembelajaran konvensional.

Implikasi penelitian berdasarkan penelitian yang telah dilakukan adalah sebagai berikut. Pertama, pelaksanaan pembelajaran daring dengan perpaduan Asinkronus dan Sinkronus mampu memperbaiki proses pembelajaran daring yang awalnya hanya cenderung dilakukan dengan metode Asinkronus saja. Pembelajaran daring dengan perpaduan Asinkronus dan Sinkronus membuat siswa belajar lebih bersemangat dan lebih mudah memahami materi yang diberikan guru. Kedua, pelaksanaan pembelajaran daring dengan perpaduan Asinkronus dan Sinkronus membuat guru lebih mudah menilai pengetahuan, sikap maupun keterampilan siswa 
dalam proses pembelajaran. Hal ini membuat penilaian yang lebih objektif dalam proses pembelajaran.

\section{Simpulan dan Saran}

Berdasarkan penelitian yang telah dilakukan, dapat ditarik simpulan sebagai berikut. Terdapat pengaruh yang signifikan pembelajaran daring dengan perpaduan Asinkronus dan Sinkronus terhadap minat belajar siswa kelas X IPS dengan Fhitung sebesar 79,477 dan signifikansi 0,00 . Terdapat pengaruh yang signifikan pembelajaran daring dengan perpaduan Asinkronus dan Sinkronus terhadap prestasi belajar siswa kelas X IPS dengan Fhitung sebesar 39,724 dan signifikansi 0,00. Secara bersama-sama, terdapat pengaruh yang signifikan pembelajaran daring dengan perpaduan Asinkronus dan Sinkronus terhadap minat dan prestasi belajar siswa kelas X IPS dengan Fhitung sebesar 50,575 dan signifikansi 0,00.

Saran yang dapat disampaikan berdasarkan penelitian yang telah dilakukan adalah sebagai berikut. Siswa disarankan untuk selalu giat dan disiplin dalam belajar, walaupun pembelajaran dilaksanakan secara daring. Guru disarankan untuk menggunakan berbagai variasi dalam proses pembelajaran daring, sehingga siswa tidak cepat merasa jenuh dalam mengikuti proses pembelajaran. Sekolah disarankan untuk berusaha menyiapkan sarana dan prasarana yang dibutuhkan guru dan siswa dalam proses pembelajaran daring. Peneliti lain disarankan untuk mengembangkan penelitian ini dengan menggunakan berbagai macam variasi pembelajaran dalam pembelajaran daring.

\section{Daftar Pustaka}

Ferazona, S. (2020). Pengaruh Pembelajaran Daring Terhadap Hasil Belajar Kognitif Mahasiswa Pada Mata Kuliah Limnologi. Journal of Research and Education Chemistry (JREC), 2(2).

Jamil, S. H., \& I. D. A. (2020). Pengaruh Pembelajaran Daring Terhadap Minat Belajar Mahasiswa Pada Masa Pandemik Covid-19. Behavioral Accounting Journal, 3(1).

Jusmawati, D. (2020). Pengaruh Pembelajaran Berbasis Daring Terhadap Minat Belajar Mahasiswa PGSD Unimerz Pada Mata Kuliah Pendidikan Matematika. Jurnal Kajian Pendidikan Dasar, 5(2).

Nugraha, S. A. D. (2020). Studi Pengaruh Daring Learning Terhadap Hasil Belajar Matematika Kelas IV. Jurnal Inovasi Penelitian, 1(3).

Nurfani, H. (2020). Pengaruh Kuliah Online Terhadap Minat Belajar Mahasiswa Pendidikan Agama Islam (PAI) di IAIN Samarinda. Borneo Journal of Islamic Studies, 2(2).

Setiabudi, F. (2008). Pengaruh pengalaman praktik, pengetahuan tentang lapangan dan Minat Belajar terhadap Kesiapan kerja Siswa SMK. Airlangga University.

Sijabat, A. D. (2020). Pengaruh Pembelajaran Daring Terhadap Minat Belajar Mahasiswa Pendidikan Fisika Uhkbpnp Pada Matakuliah Fisika Umum. Proceeding National Conference : Education, Social, Science, and Humaniora, 2(1).

Sugiyono. (2010). Metode Penelitian Pendidikan Pendekatan Kauntitatif, Kualitatif, R\&D. In Metode Penelitian Pendidikan Pendekatan Kuantitatif, Kualitatif Dan R\&D.

Sutriyani, W. (2020). Studi Pengaruh Daring Learning Terhadap Minat dan Hasil Belajar Matematika Mahasiswa PGSD Era Pandemi Covid-19. Jurnal Tunas Nusantara, 2(1), 155165. 